\title{
Costs of examinations performed in a hospital laboratory in Chile
}

\author{
Costos de exámenes en un laboratorio clínico hospitalario de Chile \\ Custos de exames em um laboratório clínico hospitalar no Chile
}

\author{
Germán Lobos Andrade', Carolina Salas Palma" \\ ' Universidad de Talca, Faculty of Business. Talca, Chile. \\ "Hospital Dr. Luis Calvo Mackenna, Clinical Laboratory Unit. Providencia, Santiago, Chile.
}

How to cite this article:
Lobos G, Salas C. Costs of examinations performed in a hospital laboratory in Chile.

Rev Bras Enferm [Internet]. 2018;71(2):363-71. DOI: http://dx.doi.org/10.1590/0034-7167-2016-0688

\section{Submission: 02-14-2017 Approval: 04-25-2017}

\section{ABSTRACT}

Objective: To determine the total average costs related to laboratory examinations performed in a hospital laboratory in Chile. Method: Retrospective study with data from July 2014 to June 2015. 92 examinations classified in ten groups were selected according to the analysis methodology. The costs were estimated as the sum of direct and indirect laboratory costs and indirect institutional factors. Results: The average values obtained for the costs according to examination group (in USD) were: 1.79 (clinical chemistry), 10.21 (immunoassay techniques), 13.27 (coagulation), 26.06 (high-performance liquid chromatography), 21.2 (immunological), 3.85 (gases and electrolytes), 156.48 (cytogenetic), 1.38 (urine), 4.02 (automated hematological), 4.93 (manual hematological). Conclusion: The value, or service fee, returned to public institutions who perform laboratory services does not adequately reflect the true total average production costs of examinations.

Descriptors: Average Costs; Diagnoses and Laboratory Examinations; Direct and Indirect Costs; Service Fee; Production of Examinations.

\section{RESUMEN}

Objetivo: determinar los costos medios totales asociados a la realización de exámenes de laboratorio en un laboratorio clínico hospitalario de Chile. Método: estudio retrospectivo con información del período julio 2104 a junio 2015. Se seleccionaron 92 exámenes clasificados en diez grupos según la metodología de análisis. Los costos se estimaron como la suma de costos directos e indirectos de laboratorio y factores indirectos institucionales. Resultados: se obtuvieron los valores promedio para los costos según grupo de exámenes (en dólares): 1,79 (química clínica), 10,21 (técnicas de inmunoensayos), 13,27 (coagulación), 26,06 (cromatografía líquida de alta resolución), 21,2 (inmunológicos), 3,85 (gases y electrolitos), 156,48 (citogenéticos), 1,38 (orina), 4,02 (hematológicos automatizados), 4,93 (hematológicos manuales). Conclusión: el valor que retorna a las instituciones públicas, o arancel por servicio, que prestan servicios de laboratorio no refleja adecuadamente los verdaderos costos medios totales de producción de exámenes.

Descriptores: Costos Medios; Diagnósticos y Exámenes de Laboratorio; Costos Directos e Indirectos; Arancel por Servicio; Producción de Exámenes.

\section{RESUMO}

Objetivo: Determinar os custos médios totais associados à realização de exames laboratoriais em um laboratório clínico hospitalar no Chile. Método: Estudo retrospectivo com informações de julho de 2014 a junho de 2015. Foram selecionados 92 exames classificados em dez grupos de acordo com a metodologia de análise. Os custos foram estimados como a soma dos custos diretos e indiretos de laboratório e fatores institucionais indiretos. Resultados: Os valores médios dos custos foram obtidos de acordo com o grupo de exames (em dólares): 1,79 (química clínica), 10,21 (técnicas de imunoensaio), 13,27 (coagulação), 26,06 (cromatografia líquida de alta resolução), 21,2 (imunológicos), 3,85 (gases e eletrólitos), 156,48 (citogenéticos), 1,38 (urina), 4,02 (hematológicos automáticos), 4,93 (hematológicos manuais). Conclusão: $O$ valor retornado às instituições públicas, ou taxas de serviço, que prestam serviços laboratoriais não refletem adequadamente os custos totais reais da produção de exames. Descritores: Custos Médios; Diagnósticos e Exames Laboratoriais; Custos Diretos e Indiretos; Tarifa de Serviço; Produção de Exames. 


\section{INTRODUCTION}

In the management of health services, like those of a clinical laboratory, criteria are applied in the operational and scientific planning, and others are applied that are inherent to the social sciences, like those used in human resources management or economic-administrative management ${ }^{(1)}$. In a clinical laboratory LC, it is fundamental to have reliable and up-to-date information on the magnitude of the total cost (CT) of the examinations processed as a basis to improve efficiency. Knowing the costs is a valuable contribution to the management of the hospitals for two reasons. First, because in a scenario of increasing demand for examinations, costs are permanently rising; it is estimated that expenditure on laboratory examinations for a hospitalized patient is $6 \%$ of the total cost and for a surgical patient $9 \%$ of the total cost of hospitalization ${ }^{(2)}$. Second, given the possible existence of "economies of scale", i.e., that the cost per examination produced, the total average cost (CMT) decreases as more examinations are performed ${ }^{(3)}$. This is possible to apply using the instrumentation and human resources available, but it has a limit given the existence of fixed factors transformed into limiting factors for the expansion of laboratory production. Therefore, cost estimation is a fundamental tool for the management oversight of a hospital clinical laboratory, as it enables approximation of the economic production cost (i.e., knowing all the costs including the opportunity costs), which allows among other things estimation of the price that should be charged for the service, knowing the profitability as a percentage of the price, and planning the destination of surpluses, when the income for examination services are greater than the total costs of these services. Although the factors that influence the cost of an examination are easily identifiable, there is not much information or many ad hoc costing models on the issue. As background, the literature shows that for clinical examinations more than half of the cost of the examination is direct labor ${ }^{(4)}$, which is why it is important to increase productivity to reduce the unit production costs ${ }^{(5)}$. Most studies describe clinical laboratory cost systems as being based on their assignability, i.e., direct and indirect costs ${ }^{(6-10)}$.

In the Chilean public health system, examinations are coded by the National Health Insurance System (FONASA). This entity is in charge of giving a unique code to practically all laboratory examinations as well as assigning them a monetary value. This coding and valuation system is called the "FONASA institutional attention modality" (F-IAM) fee and it is the value that each public institution receives when they render these services. If this fee is not in line with the true CMT of producing examinations, then the economic return to the institutions in laboratory examinations could be creating gaps for public health institutions. These gaps between income and costs may be due to production (in) efficiencies associated with institutional, management, financing, socioeconomic and demographic factors ${ }^{(11)}$. An efficiency analysis, however, is beyond the scope of this study.

In Chile there are two recent studies on the costs of health services. The first study included twelve service providers, nine public and three private, and 738 laboratory and $218 \mathrm{im}$ aging services ${ }^{(12)}$. The second included 16 public hospitals selected by convenience and 120 services with the F-IAM fee ${ }^{(13)}$.
The results of this study indicate that the prices of the services are undervalued as they do not cover $43.7 \%$ of the invoicing, although the gaps differ by health center.

At the moment the valuation of examination costs used in the clinical laboratory of the Hospital Dr. Luis Calvo Mackenna (HCM) does not identify in any integrated way all the costs that affect their performance. Nevertheless, our central hypothesis is that the F-IAM fee differs from the HCM's valuation because the costing methodology applied by FONASA only includes some of the production costs currently valued by the HCM. Thus, this work has two objectives: The first is to determine the total average costs related to laboratory examinations processed in the clinical laboratory unit of the HCM. This involves allocating all the relevant $\operatorname{costs}^{(7)}$ that influence the performance of each examination, which will make it possible to verify the status of the costs of the HCM compared to the F-IAM fee. The second objective is to compare the F-IAM fee with the total average costs for a selected group of examinations in order to identify the gap between the economic return and the average production cost.

\section{METHOD}

\section{Ethical aspects}

The use of the information in this study was authorized by the Director of the HCM. The results will be "a contribution to optimizing the management" of the institution.

\section{Design, study site and period}

This is a retrospective study with complete information from one calendar year. Quantitative information was used; the data were extracted from primary sources of the CL of the HCM. The information used corresponds to data from July 2014 to June 2015.

\section{Population or sample; inclusion and exclusion criteria}

170 types of examinations were processed during the study period. 92 representative examinations were selected from all the methodology types of analyses available in the CL. The 92 examinations were classified in 10 groups (G1, .., G10) according to the analytical technique used. The number of examinations included in each group and the technique used were: G1 $=35$ (clinical chemistry), G2 = 16 (immunoassay-based techniques), G3 $=9$ (coagulation), G4 $=3$ (performed by high performance liquid chromatography, HPLC), G5 = 8 (immunological), G6 = 2 (gases and electrolytes), G7 = 4 (cytogenetic), G8 = 1 (urine by microscopy), G9 = 1 (automated hematological), $\mathrm{G} 10=13$ (hematological by manual techniques).

\section{Theoretical-methodological and conceptual framework}

This article is derived from the Master in Health Management Systems thesis entitled, "Estimation of costs of clinical laboratory services in the Hospital Dr. Luis Calvo Mackenna". For each type of examination, the total average cost $\left(\mathrm{CMT}_{\mathrm{i}, \mathrm{j}}\right)$ was calculated as the sum of the direct average laboratory costs $\left(\mathrm{CMDL}_{i, j}\right)$, indirect average laboratory costs $\left(\mathrm{CMIL}_{\mathrm{i}, \mathrm{j}}\right)$ and average indirect institutional costs $\left(\mathrm{CMII}_{i, j}\right)$. This is:

$$
\mathrm{CMT}_{i, j}=\mathrm{CMDL}_{i, j}+\mathrm{CMIL}_{i, j}+\mathrm{CMII}_{i, j}
$$


In Equation (1) subindex $i$ indicates the type of examination $(i=1, \ldots, 92)$ and subindex $j$ indicates the group to which the type of examination $i$ belongs $(j=1, \ldots, 10$ ). Additionally, the total average cost $\left(\mu_{\mathrm{j}}\right)$ and the standard deviation $\left(\sigma_{j}\right)$ of each group of examinations were calculated.

$\mathrm{CMDL}_{i, j}$ refer to costs related directly to processing the examinations; $\mathrm{CMIL}_{\mathrm{i}, \mathrm{j}}$ are all the costs not directly related to the production of an examination. To collect the data regarding the direct and indirect costs, an Excel spreadsheet was used that included a page dedicated to identifying and quantifying each cost type. The direct costs included reagents $\left(\mathrm{RC}_{\mathrm{i}, \mathrm{j}}\right)$, internal controls $\left(\mathrm{Cl}_{\mathrm{i}, \mathrm{j}}\right)$, external controls $\left(\mathrm{CE}_{\mathrm{i}, \mathrm{j}}\right)$ and direct labor $\left(\mathrm{MOD}_{\mathrm{i}, \mathrm{j}}\right)$. The indirect laboratory costs included indirect labor $\left(\mathrm{MOI}_{\mathrm{i}, \mathrm{j}}\right)$, main equipment $\left(E_{i, j}\right)$, infrastructure $\left(I_{i, j}\right)$, furniture $\left(M B_{i, j}\right)$, general supplies $\left(\mathrm{IG}_{i, j}\right)$, office supplies $\left(A F_{i, j}\right)$, and maintenance and repairs $\left(\mathrm{MR}_{\mathrm{i}, \mathrm{j}}\right)$. Indirect institutional costs included basic services $\left(\mathrm{SB}_{\mathrm{i}, \mathrm{j}}\right)$ and general services $\left(\mathrm{SG}_{\mathrm{i}, \mathrm{j}}\right.$ ). For the analysis of reagent costs, all the supplies with the respective yields were identified and quantified. The information about the purchase price was obtained from the monthly purchase lists made in the laboratory. In order to estimate the labor cost, laboratory personnel salary information was requested from human resources; this information was differentiated in relation to the unit to which each of them belongs and was associated with the respective group of examinations.

\section{Average direct laboratory costs}

Reagents: For each $\mathrm{RC}_{\mathrm{i}, \mathrm{j}}$ the average consumption per purchase unit and the cost of each of these units were calculated. The average cost was calculated as the ratio between the individual value of $R_{i, j}$ and the number of examinations reported with this reagent.

Internal controls: These are controls used periodically to verify the analytical behavior of the technique, the objective of which is to control the results that the CL provides. To do this, control samples (commercial preparations) of known value were used. The $\mathrm{Cl}_{\mathrm{i}, \mathrm{j}}$ used for each type of examination were identified , and it was estimated how many examinations were possible to report for each purchase unit. The average cost was calculated as the ratio between the individual value of each $\mathrm{Cl}_{i, j}$ kit and the number of examinations reported with this kit. For the case of more than one $\mathrm{Cl}_{i, j}$, this was determined in the same way and then the contributions from each were added.

External controls: These are controls used to verify the analytical behavior of each technique and to compare them to those obtained by different laboratories for the same examinations. The $\mathrm{CE}_{\mathrm{i}, \mathrm{j}}$ used for each of the examinations were identified and it was estimated how many examinations could be reported for each purchase unit. The average cost was calculated as the ratio between the individual value of each $\mathrm{CE}_{\mathrm{i}, j}$ kit or program and the number of examinations reported with this kit. For the case of more than one $\mathrm{CE}_{\mathrm{i}, \mathrm{j}}$ this was determined in the same way and then the contributions of each were added.

Direct labor: The annual cost in remunerations included all the personnel in the $C L$ who participate directly in the performance of an examination: the unit head, professionals and laboratory technicians. The average cost of $\mathrm{MOD}_{i, j}$ was estimated as the ratio between the annual cost in remunerations of the direct personnel and the number of examinations reported by the $\mathrm{CL}$ in the same period.

\section{Average indirect laboratory costs}

This study included the alternative cost of the capital as a proxy variable of the depreciation for the assets $\mathrm{EP}_{i, j^{\prime}} \mathrm{ES}_{i, j^{\prime}} \mathrm{IN}_{\mathrm{i}, j}$ and $M B_{i, j}$. In each case the annual replacement cost (CRA) was calculated as its commercial value (VC) multiplied by the simple formula of payment amortization:

$$
\mathrm{CRA}=\mathrm{VC}\left[\frac{(1+r)^{n} \times r}{(1+r)^{n}-1}\right]
$$

where $\mathrm{n}$ is the remaining useful life estimated for each asset and $r=6 \%$ is the social discount rate reported by the Chilean Ministry of Social Development (MIDESO) in 2016.

Indirect labor: The annual cost in remunerations of all the personnel in the CL who participate indirectly in the performance of examinations and who provide cross-sectional support to all the specialized units in the CL. This is the general laboratory head, receiving laboratory technicians and laboratory assistants. The average cost of the $\mathrm{MOI}_{i, j}$ was estimated as the ratio between the annual cost in remunerations of indirect personnel and the number of examinations reported by the $\mathrm{CL}$ in the same period.

Main equipment: This is used to process the laboratory examinations included in the work. The average cost assigned to each examination processed was obtained as the ratio between the CRA ( $n=10$ ) of the $\mathrm{EP}_{\mathrm{i}, \mathrm{j}}$ and the annual production of examinations performed on the equipment.

Laboratory support equipment: This is the basic equipment in the $\mathrm{CL}$ which serves as support for all the examinations processed in this unit. This includes such equipment as centrifuges, hoods, thermoregulated baths, analytical balances and ovens, among other things. The average cost assigned to each examination was obtained as the ratio between the sum of the CRA ( $n=10$ ) of all the $\mathrm{ES}_{\mathrm{i}, \mathrm{j}}$ and the annual production of examinations performed in the CL.

Infrastructure: The surface occupied by the $\mathrm{CL}$ with respect to the total surface of the HCM was estimated (in \%). This percentage was multiplied by the commercial value of the infrastructure of the HCM to obtain the commercial value of the infrastructure allocated to the CL. The CRA associated with infrastructure use was obtained as the commercial value allocated to the $C L$ multiplied by the social discount rate. Thus, the average cost assigned to each examination was obtained as the ratio between the TAC $(n \rightarrow \infty)$ of the $\mathrm{IN}_{\mathrm{i}, \mathrm{j}}$ and the annual production of examinations performed in the $C L$.

Furniture: This included office furniture, computers, printers, telephones, various dispensers and chairs, among other things. The average cost assigned to each examination was obtained as 
the ratio between the sum of the CRA ( $n=10$ ) of all the $M B_{i, j}$ and the annual production of examinations performed in the $\mathrm{CL}$.

General supplies: This included all the general supplies used in the $\mathrm{CL}$ during the period, which are used cross-sectionally to process all the examinations performed in the $\mathrm{CL}$, such as gloves, Eppendorf tubes, tips for micropipettes, droppers, etc. The average cost assigned to each examination was obtained as the ratio between the sum of the costs of all the $I_{\mathrm{i}}$, and the annual production of examinations performed in the $\mathrm{CL}$.

Office supplies: This included all the office supplies used in the $C L$ during the period, which are used interchangeably in the production of all the laboratory examinations. The average cost assigned to each examination was obtained as the ratio between the sum of the costs of all the $A F_{i, j}$ and the annual production of examinations performed in the CL unit.

Maintenance and repairs: This included the costs of maintenance and repairs of buildings, furniture, machinery and office equipment, CL equipment and other maintenance and repairs of each unit in the $\mathrm{CL}$. The average cost assigned to each examination was obtained as the ratio between the sum of the costs in $M R_{i, j}$ and the annual production of examinations performed in the $\mathrm{CL}$ unit.

\section{Average indirect institutional costs}

Basic services: This included the cost of electricity, water, gas, telephones, Internet and telecommunications links. The average cost assigned to each examination was obtained as the ratio between the sum of the costs in $\mathrm{SB}_{\mathrm{i}, \mathrm{j}}$ and the annual production of examinations performed in the $C L$ unit.

General services: This included the cost of janitorial services, security, landscaping, trash and hazardous waste collection, transportation, shipping, storage and other general services. The average cost assigned to each examination was obtained as the ratio between the sum of the costs in $\mathrm{SG}_{\mathrm{i}}$ and the annual production of examinations performed in the $\mathrm{CL}$ unit.

\section{Results analysis}

The F-IAM fee was compared with the CMT for a selected group of examinations. The profitability ${ }^{(14)}$ of each examination was calculated as the difference between the F-IAM fee and the CMTexpressed as a percentage of the F-IAM fee. Finally, and given the total number of examinations performed for each type of examination selected, the total production cost (TPC) of examinations was compared with the total income (TI) derived from the total contribution by the F-IAM fee.

\section{RESULTS}

In the area of clinical chemistry $\left(G_{1}\right)$, the most expensive examination was ammonium at 4.64 USD and the least expensive were cholesterol and triglycerides at 1.05 USD (Table 1). The average cost $\left(\mu_{1}\right)$ and the standard deviation $\left(\sigma_{1}\right)$ of this group of examinations was estimated to be 1.79 and 1.12 USD, respectively.

Table 1 - Total average cost of examinations in the area of clinical chemistry (G_1 ), Values in USD

\begin{tabular}{|c|c|c|c|c|c|c|c|}
\hline \multirow{2}{*}{ Group and exam description } & \multicolumn{3}{|c|}{ Average direct laboratory costs (ADLC) } & \multirow{2}{*}{$\begin{array}{l}\text { Sub-total } \\
\text { ADLC }\end{array}$} & \multicolumn{2}{|c|}{$\begin{array}{l}\text { Sub-total Average Indirect } \\
\text { Laboratory and Indirect } \\
\text { Institutional Costs }\end{array}$} & \multirow{2}{*}{$\begin{array}{c}\text { Total } \\
\text { Average } \\
\text { Cost } \\
\text { (TAC) }\end{array}$} \\
\hline & Reagents & $\begin{array}{l}\text { Internal and } \\
\text { external controls }\end{array}$ & $\begin{array}{l}\text { Direct } \\
\text { labor }\end{array}$ & & AILC & AlIC & \\
\hline \multicolumn{8}{|l|}{ Clinical chemistry ( G1 ) } \\
\hline Uric acid & 0.27 & 0.03 & 0.50 & 0.81 & 0.25 & 0.08 & 1.13 \\
\hline Albumin & 0.24 & 0.01 & 0.50 & 0.74 & 0.25 & 0.08 & 1.07 \\
\hline Amikacin plasma levels & 3.46 & 0.03 & 0.50 & 3.99 & 0.25 & 0.08 & 4.32 \\
\hline Amylase & 0.50 & 0.01 & 0.50 & 1.01 & 0.25 & 0.08 & 1.33 \\
\hline Ammonium & 3.81 & 0.00 & 0.50 & 4.31 & 0.25 & 0.08 & 4.64 \\
\hline Unconjugated bilirubin (BuBc) & 0.24 & 0.01 & 0.50 & 0.75 & 0.25 & 0.08 & 1.07 \\
\hline Total bilirubin & 0.25 & 0.01 & 0.50 & 0.76 & 0.25 & 0.08 & 1.08 \\
\hline $\mathrm{C} 3$ & 2.72 & 0.03 & 0.50 & 3.24 & 0.25 & 0.08 & 3.57 \\
\hline C4 & 2.74 & 0.03 & 0.50 & 3.27 & 0.25 & 0.08 & 3.59 \\
\hline Calcium & 0.24 & 0.03 & 0.50 & 0.77 & 0.25 & 0.08 & 1.10 \\
\hline $\mathrm{CK}$ & 0.50 & 0.01 & 0.50 & 1.00 & 0.25 & 0.08 & 1.33 \\
\hline CK MB & 0.58 & 0.01 & 0.50 & 1.09 & 0.25 & 0.08 & 1.41 \\
\hline Cholesterol & 0.22 & 0.01 & 0.50 & 0.73 & 0.25 & 0.08 & 1.05 \\
\hline Creatinine & 0.24 & 0.03 & 0.50 & 0.77 & 0.25 & 0.08 & 1.10 \\
\hline Rheumatoid factor & 3.18 & 0.00 & 0.50 & 3.69 & 0.25 & 0.08 & 4.01 \\
\hline Alkaline Phosphatase & 0.25 & 0.01 & 0.50 & 0.75 & 0.25 & 0.08 & 1.08 \\
\hline Phosphorus & 0.25 & 0.03 & 0.50 & 0.78 & 0.25 & 0.08 & 1.10 \\
\hline GGT & 0.38 & 0.01 & 0.50 & 0.88 & 0.25 & 0.08 & 1.21 \\
\hline
\end{tabular}




\begin{tabular}{|c|c|c|c|c|c|c|c|}
\hline \multirow{2}{*}{ Group and exam description } & \multicolumn{3}{|c|}{ Average direct laboratory costs (ADLC) } & \multirow{2}{*}{$\begin{array}{l}\text { Sub-total } \\
\text { ADLC }\end{array}$} & \multicolumn{2}{|c|}{$\begin{array}{l}\text { Sub-total Average Indirect } \\
\text { Laboratory and Indirect } \\
\text { Institutional Costs }\end{array}$} & \multirow{2}{*}{$\begin{array}{c}\text { Total } \\
\text { Average } \\
\text { Cost } \\
\text { (TAC) }\end{array}$} \\
\hline & Reagents & $\begin{array}{c}\text { Internal and } \\
\text { external controls }\end{array}$ & $\begin{array}{l}\text { Direct } \\
\text { labor }\end{array}$ & & AILC & AIIC & \\
\hline \multicolumn{8}{|l|}{ Clinical chemistry ( G1) } \\
\hline Glucose & 0.21 & 0.03 & 0.50 & 0.75 & 0.25 & 0.08 & 1.07 \\
\hline GOT/AST & 0.25 & 0.01 & 0.50 & 0.76 & 0.25 & 0.08 & 1.09 \\
\hline GPT / ALT & 0.24 & 0.01 & 0.50 & 0.75 & 0.25 & 0.08 & 1.08 \\
\hline $\mathrm{HDL}$ & 1.14 & 0.01 & 0.50 & 1.64 & 0.25 & 0.08 & 1.97 \\
\hline $\lg A$ & 2.61 & 0.01 & 0.50 & 3.12 & 0.25 & 0.08 & 3.45 \\
\hline $\lg G$ & 2.63 & 0.01 & 0.50 & 3.13 & 0.25 & 0.08 & 3.46 \\
\hline $\lg M$ & 2.03 & 0.01 & 0.50 & 2.54 & 0.25 & 0.08 & 2.87 \\
\hline Lactate & 0.52 & 0.01 & 0.50 & 1.03 & 0.25 & 0.08 & 1.36 \\
\hline $\mathrm{LDH}$ & 0.25 & 0.01 & 0.50 & 0.76 & 0.25 & 0.08 & 1.09 \\
\hline Lipase & 0.76 & 0.01 & 0.50 & 1.27 & 0.25 & 0.08 & 1.60 \\
\hline Magnesium & 0.25 & 0.01 & 0.50 & 0.76 & 0.25 & 0.08 & 1.09 \\
\hline Blood urea nitrogen (BUN) & 0.24 & 0.03 & 0.50 & 0.77 & 0.25 & 0.08 & 1.09 \\
\hline C-reactive protein & 0.83 & 0.00 & 0.50 & 1.33 & 0.25 & 0.08 & 1.66 \\
\hline LCR Protein & 0.43 & 0.00 & 0.50 & 0.93 & 0.25 & 0.08 & 1.25 \\
\hline Total protein & 0.24 & 0.01 & 0.50 & 0.75 & 0.25 & 0.08 & 1.07 \\
\hline Urine Protein & 0.28 & 0.02 & 0.50 & 0.80 & 0.25 & 0.08 & 1.13 \\
\hline Triglycerides & 0.22 & 0.01 & 0.50 & 0.73 & 0.25 & 0.08 & 1.05 \\
\hline
\end{tabular}

Note: AC: Average Cost; AILC: Average indirect laboratory cost; AllC: Average indirect institutional cost.

The costs of examinations in the immunoassay $\left(\mathrm{G}_{2}\right)$ and coagulation $\left(\mathrm{G}_{3}\right.$ ) groups are shown in Table 2. In $\mathrm{G}_{2}$ the most and least expensive examinations were cyclosporine plasma level at 18.41 USD and free T4 at 3.69 USD. In this group $\mu_{2}=10.21$ and $\sigma_{2}=4.49$. In $\mathrm{G}_{3}$ the most and least expensive examinations were lupus anticoagulant at 19.81 USD and TTPA at 2.82 USD. In this group $\mu_{3}=13.27$ and $\sigma_{3}=7.62$.

The examinations done using $\operatorname{HPLC}\left(\mathrm{G}_{4}\right)$, immunology $\left(\mathrm{G}_{5}\right)$ and gases and electrolytes $\left(\mathrm{G}_{6}\right.$ ) are in Table 3. In $\mathrm{G}_{4}$ the most and least expensive examinations were voriconazole plasma level at 26.78 USD and mycophenolic acid plasma level at 24.53 USD. In this group $\mu_{4}=26.06$ and $\sigma_{4}=1.33$. In $\mathrm{G}_{5}$ the most and least expensive examinations were antineutrophil cytoplasmic antibody (CANCA) at 29.91 USD and antiendomysial antibody at 15.29 USD. In this group $\mu_{5}=21.2$ and $\sigma_{5}=5.55$. In $\mathrm{G}_{6}$ the costs of the examinations were 5.35 USD for urinary electrolytes and 2.30 USD for arterial blood gases + plasma electrolytes. In this group $\mu_{6}=3.85$ and $\sigma_{6}=2.18$.
In the cytogenetic group $\left(\mathrm{G}_{7}\right)$ the most expensive examination was FISH at 207.41 USD and the least expensive was the karyogram blood test with lymphocyte culture at 128.09 USD. In this group $\mu_{7}=156.48$ and $\sigma_{7}=36.05$. In the urine by microscopy group $\left(\mathrm{G}_{8}\right)$ the cost of the full urine examination was 1.38 USD. In the automated hematology group $\left(\mathrm{G}_{q}\right)$ the cost of the blood picture examination + reticulocyte count was 4.02 USD. Finally, in the hematology by manual techniques group $\left(G_{10}\right)$ the most expensive examination was hemoglobin electrophoresis at 19.13 USD and the least expensive was reticulocyte count at 1.75 USD. In this group $\mu_{10}=4.93$ and $\sigma_{10}=4.95$ (Table 4).

Table 5 presents the results of the comparison of the F-IAM fee and the TAC for a selected group of 32 examinations. The highest profitability was observed in CK MB with $74.5 \%$ and lowest was $-170.1 \%$ for karyogram in fibroblast with tissue culture. The total cost for the group of 32 selected examinations was estimated to be 607,936 USD, whereas the total income for examination services was estimated to be 608,050 USD.

Table 2 - Total average cost of examinations based on immunoassay $\left(\mathrm{G}_{2}\right.$ ) and coagulation techniques $\left(\mathrm{G}_{3}\right)$, Values in USD

\begin{tabular}{|c|c|c|c|c|c|c|c|}
\hline \multirow{2}{*}{ Group and exam description } & \multicolumn{3}{|c|}{ Average direct laboratory costs (ADLC) } & \multirow{2}{*}{$\begin{array}{c}\text { Sub-total } \\
\text { ADLC }\end{array}$} & \multicolumn{2}{|c|}{$\begin{array}{l}\text { Sub-total Average Indirect } \\
\text { Laboratory and Indirect } \\
\text { Institutional Costs }\end{array}$} & \multirow{2}{*}{$\begin{array}{l}\text { Total } \\
\text { Average } \\
\text { Cost } \\
\text { (TAC) }\end{array}$} \\
\hline & Reagents & $\begin{array}{c}\text { Internal and } \\
\text { external controls }\end{array}$ & $\begin{array}{l}\text { Direct } \\
\text { labor }\end{array}$ & & AILC & AlIC & \\
\hline \multicolumn{8}{|l|}{ Immunoassays (G2) } \\
\hline 25-Hydroxy Vitamin D & 20.64 & 0.03 & 0.50 & 21.17 & 0.85 & 0.08 & 22.09 \\
\hline Alpha-fetoprotein & 6.64 & 0.71 & 0.50 & 7.84 & 0.85 & 0.08 & 8.77 \\
\hline aTG & 8.90 & 0.00 & 0.50 & 9.40 & 0.85 & 0.08 & 10.32 \\
\hline aTPO & 8.47 & 0.00 & 0.50 & 8.97 & 0.85 & 0.08 & 9.90 \\
\hline
\end{tabular}




\begin{tabular}{|c|c|c|c|c|c|c|c|}
\hline \multirow{2}{*}{ Group and exam description } & \multicolumn{3}{|c|}{ Average direct laboratory costs (ADLC) } & \multirow{2}{*}{$\begin{array}{l}\text { Sub-total } \\
\text { ADLC }\end{array}$} & \multicolumn{2}{|c|}{$\begin{array}{l}\text { Sub-total Average Indirect } \\
\text { Laboratory and Indirect } \\
\text { Institutional Costs }\end{array}$} & \multirow{2}{*}{$\begin{array}{c}\text { Total } \\
\text { Average } \\
\text { Cost } \\
\text { (TAC) }\end{array}$} \\
\hline & Reagents & $\begin{array}{c}\text { Internal and } \\
\text { external controls }\end{array}$ & $\begin{array}{l}\text { Direct } \\
\text { labor }\end{array}$ & & AILC & AllC & \\
\hline \multicolumn{8}{|l|}{ Immunoassays (G2) } \\
\hline Cyclosporine Plasma Level & 16.84 & 0.15 & 0.50 & 17.49 & 0.85 & 0.08 & 18.41 \\
\hline Cortisol & 6.26 & 0.03 & 0.50 & 6.79 & 0.85 & 0.08 & 7.72 \\
\hline Ferritin & 5.41 & 0.03 & 0.50 & 5.95 & 0.85 & 0.08 & 6.87 \\
\hline Chorionic gonadotropin & 7.50 & 0.03 & 0.50 & 8.03 & 0.85 & 0.08 & 8.96 \\
\hline Insulin & 4.83 & 0.03 & 0.50 & 5.36 & 0.85 & 0.08 & 6.29 \\
\hline Methotrexate Plasma Level & 11.74 & 0.00 & 0.50 & 12.24 & 0.85 & 0.08 & 13.17 \\
\hline PTH & 11.66 & 0.00 & 0.50 & 12.16 & 0.85 & 0.08 & 13.09 \\
\hline T4 & 2.69 & 0.05 & 0.50 & 3.24 & 0.85 & 0.08 & 4.16 \\
\hline Free T4 & 2.23 & 0.04 & 0.50 & 2.77 & 0.85 & 0.08 & 3.69 \\
\hline Tacrolimus Plasma Level & 16.70 & 0.15 & 0.50 & 17.34 & 0.85 & 0.08 & 18.26 \\
\hline TSH & 2.47 & 0.05 & 0.50 & 3.01 & 0.85 & 0.08 & 3.94 \\
\hline Vancomycin Plasma Level & 6.26 & 0.03 & 0.50 & 6.79 & 0.85 & 0.08 & 7.71 \\
\hline \multicolumn{8}{|l|}{ Coagulation (G3) } \\
\hline Lupus Anticoagulant & 18.21 & 0.00 & 1.16 & 19.37 & 0.31 & 0.12 & 19.81 \\
\hline Anti-Factor X & 15.20 & 0.00 & 1.16 & 16.36 & 0.31 & 0.12 & 16.79 \\
\hline Antithrombin III & 20.42 & 0.05 & 1.16 & 21.64 & 0.31 & 0.12 & 22.07 \\
\hline Factor IX & 15.23 & 0.00 & 1.16 & 16.39 & 0.31 & 0.12 & 16.82 \\
\hline Factor VII & 15.23 & 0.00 & 1.16 & 16.39 & 0.31 & 0.12 & 16.82 \\
\hline Factor VIII & 15.23 & 0.00 & 1.16 & 16.39 & 0.31 & 0.12 & 16.82 \\
\hline Fibrinogen & 3.07 & 0.05 & 1.16 & 4.28 & 0.31 & 0.12 & 4.71 \\
\hline TP & 1.07 & 0.07 & 1.16 & 2.30 & 0.31 & 0.12 & 2.73 \\
\hline TTPA & 1.16 & 0.07 & 1.16 & 2.39 & 0.31 & 0.12 & 2.82 \\
\hline
\end{tabular}

Note: AC: Average Cost; AILC: Average indirect laboratory cost; AIIC: Average indirect institutional cost.

Table 3 - Total average cost of exams done by $\operatorname{HPLC}\left(\mathrm{G}_{4}\right)$, immunology $\left(\mathrm{G}_{5}\right)$, and gases and electrolytes $\left(\mathrm{G}_{6}\right)$, Values in USD

\begin{tabular}{|c|c|c|c|c|c|c|c|}
\hline \multirow{2}{*}{ Group and exam description } & \multicolumn{3}{|c|}{$\begin{array}{l}\text { Average direct laboratory } \\
\text { costs (ADLC) }\end{array}$} & \multirow{2}{*}{$\begin{array}{l}\text { Sub-total } \\
\text { ADLC }\end{array}$} & \multicolumn{2}{|c|}{$\begin{array}{l}\text { Sub-total Average } \\
\text { Indirect Laboratory } \\
\text { and Indirect } \\
\text { Institutional Costs }\end{array}$} & \multirow{2}{*}{$\begin{array}{l}\text { Total } \\
\text { Average } \\
\text { Cost } \\
\text { (TAC) }\end{array}$} \\
\hline & Reagents & $\begin{array}{l}\text { Internal } \\
\text { and } \\
\text { external } \\
\text { controls }\end{array}$ & $\begin{array}{l}\text { Direct } \\
\text { labor }\end{array}$ & & AILC & AlIC & \\
\hline \multicolumn{8}{|l|}{ HPLC ( G4 ) } \\
\hline Mycophenolic Ac. plasma level & 3.26 & 1.47 & 0.50 & 5.23 & 19.22 & 0.08 & 24.53 \\
\hline Voriconazole plasma level & 7.07 & 0.00 & 0.50 & 7.57 & 19.22 & 0.08 & 26.87 \\
\hline Posaconazole plasma level & 6.98 & 0.00 & 0.50 & 7.48 & 19.22 & 0.08 & 26.78 \\
\hline \multicolumn{8}{|l|}{ Immunology (G5) } \\
\hline Antitransglutaminase $\mathrm{AB}$ IgA & 9.82 & 0.15 & 5.33 & 15.30 & 1.86 & 0.56 & 17.72 \\
\hline Anti-DNA AB (aDNA) & 7.52 & 0.14 & 5.33 & 12.99 & 1.86 & 0.56 & 15.42 \\
\hline Antibody to Extractable Nuclear Antigen (aENA) profile (identification) & 16.40 & 0.86 & 5.33 & 22.59 & 1.86 & 0.56 & 25.02 \\
\hline Anti-cardiolipin AB identification (IgG or IgA) & 18.37 & 0.00 & 5.33 & 23.70 & 1.86 & 0.56 & 26.12 \\
\hline Antineutrophil cytoplasmic AB (cANCA) & 22.15 & 0.00 & 5.33 & 27.48 & 1.86 & 0.56 & 29.91 \\
\hline Antinuclear AB (ANA) & 9.17 & 0.14 & 5.33 & 14.64 & 1.86 & 0.56 & 17.06 \\
\hline Mitochondrial $\mathrm{AB}$ and anti-smooth muscle $\mathrm{AB}$. & 15.32 & 0.00 & 5.33 & 20.65 & 1.86 & 0.56 & 23.07 \\
\hline Antiendomysial $\mathrm{AB}$ & 7.54 & 0.00 & 5.33 & 12.87 & 1.86 & 0.56 & 15.29 \\
\hline \multicolumn{8}{|l|}{ Gases and electrolytes (G6) } \\
\hline Arterial blood gases/+ plasma electrolytes & 1.17 & 0.01 & 0.50 & 1.68 & 0.55 & 0.08 & 2.30 \\
\hline Urinary electrolytes & 1.07 & 0.00 & 0.50 & 1.57 & 3.75 & 0.08 & 5.39 \\
\hline
\end{tabular}


Table 4 - Total average cost of cytogenic exams $\left(\mathrm{G}_{7}\right)$, urinary $\left(\mathrm{G}_{8}\right)$, automated hematology $\left(\mathrm{G}_{9}\right)$, and hematology by manual techniques $\left(\mathrm{G}_{10}\right)$. Values in USD

\begin{tabular}{|c|c|c|c|c|c|c|c|}
\hline \multirow{2}{*}{ Group and exam description } & \multicolumn{3}{|c|}{$\begin{array}{l}\text { Average direct laboratory costs } \\
\text { (ADLC) }\end{array}$} & \multirow{2}{*}{$\begin{array}{l}\text { Sub-total } \\
\text { ADLC }\end{array}$} & \multicolumn{2}{|c|}{$\begin{array}{l}\text { Sub-total Average Indirect } \\
\text { Laboratory and Indirect } \\
\text { Institutional Costs }\end{array}$} & \multirow{2}{*}{$\begin{array}{l}\text { Total } \\
\text { Average } \\
\text { Cost } \\
\text { (TAC) }\end{array}$} \\
\hline & Reagents & $\begin{array}{l}\text { Internal and } \\
\text { external } \\
\text { controls }\end{array}$ & Direct labor & & AILC & AlIC & \\
\hline \multicolumn{8}{|l|}{ Cytogenetics (G7) } \\
\hline Karyogram blood test with lymphocyte culture & 5.55 & 0.67 & 107.79 & 114.01 & 9.69 & 4.38 & 128.09 \\
\hline Karyogram with special techniques & 11.62 & 0.67 & 107.79 & 120.09 & 9.69 & 4.38 & 134.16 \\
\hline Karyogram in fibroblast with tissue culture & 33.74 & 0.67 & 107.79 & 142.20 & 9.69 & 4.38 & 156.28 \\
\hline $\mathrm{FISH}$ & 85.55 & 0.00 & 107.79 & 193.34 & 9.69 & 4.38 & 207.41 \\
\hline \multicolumn{8}{|l|}{ Urine (G8) } \\
\hline Full urine & 0.50 & 0.02 & 0.50 & 1.03 & 0.28 & 0.08 & 1.38 \\
\hline \multicolumn{8}{|l|}{ Automated hematology (G9) } \\
\hline Blood picture + Reticulocytes & 1.07 & 1.09 & 1.16 & 3.32 & 0.58 & 0.12 & 4.02 \\
\hline \multicolumn{8}{|l|}{ Hematology by manual techniques (G10) } \\
\hline Hemogram & 1.15 & 0.00 & 1.16 & 2.31 & 0.23 & 0.12 & 2.66 \\
\hline Reticulocyte count & 0.24 & 0.00 & 1.16 & 1.40 & 0.23 & 0.12 & 1.75 \\
\hline Osmotic fragility & 0.76 & 0.00 & 1.16 & 1.92 & 0.23 & 0.12 & 2.27 \\
\hline Glucose-6-phosphate dehydrogenase & 4.25 & 0.00 & 1.16 & 5.41 & 0.23 & 0.12 & 5.76 \\
\hline Sickle cells (Drepanocytes) & 1.18 & 0.00 & 1.16 & 2.34 & 0.23 & 0.12 & 2.69 \\
\hline Peroxidases & 0.92 & 0.00 & 1.16 & 2.08 & 0.23 & 0.12 & 2.44 \\
\hline PAS (Periodic acid-Schiff) & 2.82 & 0.00 & 1.16 & 3.98 & 0.23 & 0.12 & 4.34 \\
\hline Esterases & 9.65 & 0.00 & 1.16 & 10.81 & 0.23 & 0.12 & 11.16 \\
\hline Fetal hemoglobin & 0.91 & 0.00 & 1.16 & 2.07 & 0.23 & 0.12 & 2.43 \\
\hline HAM test & 3.15 & 0.00 & 1.16 & 4.31 & 0.23 & 0.12 & 4.67 \\
\hline LCR cytology & 1.11 & 0.00 & 1.16 & 2.27 & 0.23 & 0.12 & 2.63 \\
\hline Hemoglobin electrophoresis & 17.62 & 0.00 & 1.16 & 18.78 & 0.23 & 0.12 & 19.13 \\
\hline VHS & 0.59 & 0.02 & 1.16 & 1.77 & 0.25 & 0.12 & 2.14 \\
\hline
\end{tabular}

Note: AC: Average Cost; AILC: Average indirect laboratory cost; AllC: Average indirect institutional cost.

Table 5 - Comparison of the National Health Insurance (FONASA) fee and total average cost, profitability, income and total cost of a selected group of examinations

\begin{tabular}{|c|c|c|c|c|c|c|}
\hline \multirow{2}{*}{ Exam description } & \multicolumn{2}{|c|}{$\begin{array}{l}\text { FONASA IAM fee } \\
\text { and TAC } \\
\text { (USD) }\end{array}$} & \multirow{2}{*}{$\begin{array}{c}\begin{array}{c}\text { Profitability } \\
(\%)\end{array} \\
\text { MAI - CMT } \\
\text { MAI }\end{array}$} & \multirow{2}{*}{$\begin{array}{c}\begin{array}{c}\text { Annual production } \\
\text { of examinations } \\
\text { (number) }\end{array} \\
\text { n }\end{array}$} & \multirow{2}{*}{$\begin{array}{c}\begin{array}{c}\text { TC of } \\
\text { examinations } \\
(\text { USD })\end{array} \\
\mathrm{TC}=\mathrm{n} \times \mathrm{TAC}\end{array}$} & \multirow{2}{*}{$\begin{array}{c}\begin{array}{c}\text { IT from } \\
\text { examinations } \\
\text { performed }\end{array} \\
\text { TI = n x IAM }\end{array}$} \\
\hline & IAM & TAC & & & & \\
\hline Uric acid & 1.86 & 1.13 & 39.21 & 2,711 & 3,068 & 5,047 \\
\hline Albumin & 1.71 & 1.07 & 37.32 & 18,508 & 19,810 & 31,606 \\
\hline Amikacin plasma level & 6.62 & 4.32 & 34.76 & 791 & 3,414 & 5,233 \\
\hline Amylase & 2.74 & 1.33 & 51.37 & 2,025 & 2,697 & 5,545 \\
\hline Ammonium & 2.48 & 4.64 & -87.37 & 1,241 & 5,759 & 3,074 \\
\hline Total bilirubin & 1.54 & 1.08 & 29.52 & 32,247 & 34,966 & 49,611 \\
\hline $\mathrm{C} 3$ & 5.40 & 3.57 & 33.96 & 350 & 1,248 & 1,890 \\
\hline $\mathrm{C} 4$ & 5.40 & 3.59 & 33.49 & 350 & 1,257 & 1,890 \\
\hline Calcium & 1.35 & 1.10 & 19.06 & 18,980 & 20,798 & 25,696 \\
\hline CK & 4.25 & 1.33 & 68.67 & 815 & 1,084 & 3,461 \\
\hline CK MB & 5.55 & 1.41 & 74.54 & 405 & 573 & 2,249 \\
\hline Cholesterol & 1.62 & 1.05 & 34.92 & 19,573 & 20,578 & 31,618 \\
\hline Creatinine & 1.57 & 1.10 & 29.99 & 24,900 & 27,354 & 39,074 \\
\hline Rheumatoid factor & 5.57 & 4.01 & 27.96 & 150 & 602 & 835 \\
\hline Alkaline Phosphatase & 1.58 & 1.08 & 31.88 & 18,175 & 19,617 & 28,800 \\
\hline
\end{tabular}




\begin{tabular}{|c|c|c|c|c|c|c|}
\hline \multirow{2}{*}{ Exam description } & \multicolumn{2}{|c|}{$\begin{array}{l}\text { FONASA IAM fee } \\
\text { and TAC } \\
\text { (USD) }\end{array}$} & \multirow{2}{*}{$\begin{array}{c}\begin{array}{c}\text { Profitability } \\
(\%)\end{array} \\
\text { MAI - CMT } \\
\text { MAI }\end{array}$} & \multirow{2}{*}{$\begin{array}{c}\begin{array}{c}\text { Annual production } \\
\text { of examinations } \\
\text { (number) }\end{array} \\
\text { n }\end{array}$} & \multirow{2}{*}{$\begin{array}{c}\begin{array}{c}\text { TC of } \\
\text { examinations } \\
\text { (USD) }\end{array} \\
\mathrm{TC}=\mathrm{n} \times \mathrm{TAC}\end{array}$} & \multirow{2}{*}{$\begin{array}{c}\begin{array}{c}\text { IT from } \\
\text { examinations } \\
\text { performed }\end{array} \\
\text { TI = n x IAM }\end{array}$} \\
\hline & IAM & TAC & & & & \\
\hline Phosphorus & 2.05 & 1.10 & 46.03 & 18,802 & 20,763 & 38,472 \\
\hline GGT & 2.63 & 1.21 & 54.04 & 7,022 & 8,490 & 18,473 \\
\hline Glucose & 1.57 & 1.07 & 31.72 & 19,944 & 21,369 & 31,297 \\
\hline Insulin & 6.14 & 6.29 & -2.39 & 600 & 3,771 & 3,683 \\
\hline Methotrexate Plasma Level & 6.62 & 13.17 & -99.01 & 1,000 & 13,165 & 6,615 \\
\hline $\mathrm{T} 4$ & 5.37 & 4.16 & 22.46 & 1,000 & 4,163 & 5,369 \\
\hline Free T4 & 6.14 & 3.69 & 39.90 & 1,700 & 6,272 & 10,435 \\
\hline TSH & 5.37 & 3.94 & 26.64 & 2,500 & 9,847 & 13,423 \\
\hline Vancomycin Plasma Level & 6.62 & 7.71 & -16.57 & 1,800 & 13,881 & 11,908 \\
\hline Fibrinogen & 2.48 & 4.71 & -90.24 & 1,048 & 4,938 & 2,596 \\
\hline TP & 2.12 & 2.73 & -28.54 & 5,756 & 15,708 & 12,220 \\
\hline TTPA & 2.71 & 2.82 & -4.14 & 4,668 & 13,163 & 12,640 \\
\hline Karyogram blood test with lymphocyte culture & 54.11 & 128.09 & -136.73 & 500 & 64,044 & 27,054 \\
\hline Karyogram with special techniques & 57.86 & 134.16 & -131.86 & 351 & 47,090 & 20,309 \\
\hline Karyogram in fibroblast with tissue culture & 57.86 & 156.28 & -170.09 & 55 & 8,595 & 3,182 \\
\hline Full urine & 2.22 & 1.38 & 37.49 & 12,100 & 16,757 & 26,806 \\
\hline Hemogram (includes VHS) & 3.55 & 4.81 & -35.29 & 36,000 & 173,094 & 127,938 \\
\hline Totals & & & & 256,067 & 607,936 & 608,050 \\
\hline
\end{tabular}

Note: FONASA: National Health Insurance System; IAM - Institutional attention modality, TAC - Total Average Cost, TC - Total Cost, TI - Total Income

\section{DISCUSSION}

In this work all the factors suggested by the literature for a suitable estimation of costs were considered. These were to identify the consumption of resources associated with the services, to quantify the physical consumption of resources and to assess the consumption of resources ${ }^{(5)}$. The quantification of the performance and resources used was done retrospectively and one calendar year was the analysis time; therefore, the unit costs obtained for each service include all the costs involved in the production of a unit.

The 10 groups of examinations analyzed, which included a total 92 examinations performed in the CL of the HCM, are more than $50 \%$ of the total portfolio of the CL. The examinations included correspond to several specialties and analysis methodologies (manual, semi-automated and automated).

The clinical chemistry group presents the examinations with the lowest CMT. In this group the concept of scale economy "the greater the production the lower the cost"(3) is fulfilled, as is the "80$20^{\prime \prime}$ rule $^{(3)}$, which classifies the examinations of highest production in terms of volume $(80 \%)$ as carrying the lowest cost $(20 \%)$. This is because this group of examinations are produced in the greatest volume and the labor factor is less relevant. It should be noted that labor is a difficult factor to manage in public centers, because the seniority of the human resources involves higher costs, which is not always associated with greater productivity. In addition, the tenure of the personnel must be considered, which prevents human resources from being transferred to areas of greater production depending on each worker's degree of specialization.

In the cytogenetic examinations more than $50 \%$ of the examination cost is direct labor, which is consistent with what has been reported in the literature ${ }^{(4)}$; in addition, it seems important to increase productivity to obtain lower unit production costs ${ }^{(5)}$. However, this is not always possible since such examinations are specialized and require highly qualified labor. They are also very specific examinations and in low demand.

It was noted that the total average costs of the examinations and their respective F-IAM value differed in all cases for the group of 32 examinations selected. The same occurred with the sample of 92 examinations included in this study, where in 44 cases $(47 \%)$ the CMT was higher than the F-IAM fee, whereas in 48 cases (53\%) the opposite was true. This means the F-IAM fee is not aligned with the CMT of each examination performed in the HCM. Therefore, even though the total cost is similar to the total income for examination services, it seems essential to update the F-IAM fee for laboratory costs and services. These results are consistent with those reported by the literature in terms of aligning the variables $\mathrm{F}$ IAM fee and cost in order to facilitate the financial evaluation processes and the application of financial policies and prices in health centers ${ }^{(13)}$. With respect to the costs reported by the literature $^{(12)}$ it is difficult to make comparisons if the costs are not previously adjusted by variables like complexity and number of services in each laboratory ${ }^{(13)}$.

At the aggregate level, this means that the F-IAM fee must reflect the true production cost of each examination, and to do this it is essential that the LC constantly update the CMT. It is also very important for FONASA to keep the F-IAM updated in terms of the production costs of hospital clinical laboratories in Chile. Thus, the main implication of this work is that the value returned to the public institutions who render laboratory services does not reflect the true total average production costs of examinations. 


\section{Limitations of the study}

The first limitation of the study is considered to be not having a measure of dispersion with respect to the cost of each type of examination within each group. This is because the procedure used was to estimate the total cost of producing each type of examination and then to divide it by the number of examinations of each type. Therefore, our cost estimations represent the average cost of producing a type of examination, with the possibility of a certain level of dispersion. We cannot know this dispersion because we did not record the cost of producing each examination of the same type in order to calculate the average (and the dispersion) of all the examinations of each type.

The second limitation of the study is the difficulty in valuing the assets, such as main equipment, laboratory support equipment, infrastructure and furniture. This is because in Chile procedures have been implemented to improve, among others aspects, the accounting and presentation of fixed assets in the financial statements of State organizations in general, and of public hospitals in particular. This means that hospitals must have a methodology to review their procedures on movable and immovable property, facilitating convergence towards the International Public Sector Accounting Standards (IPSAS) that came into force in 2016.

\section{Contributions of the study}

It is estimated that the main contribution of the study refers to the scope of public health policy. This means that the financing of health systems and services must be based on the correct estimation of the production costs of these systems and services, so as to converge towards an optimal (or better) allocation of the limited resources available in the health sector.

\section{CONCLUSION}

The main conclusion of this work is that the value, or service fee, returned to public institutions who perform laboratory services does not adequately reflect the true total average production costs of examinations.

\section{REFERENCES}

1. Barral M. La gestión integrada y la dinámica de sistemas: criterios a aplicar en los laboratorios clínicos. Acta Bioquím Clín Latinoam [Internet]. 2007 [cited 2017 Feb 13];41(3):407-18. Available from: http://www.scielo.org.ar/pdf/abcl/v41n3/v41n3a16.pdf

2. Young DS, Sachais BS, Jefferies LC. Laboratory cost in the context of disease. Clin Chem. 2000;46(7)967-75.

3. Caballé M. La necesidad de asignar costes en el laboratorio clínico. Quím Clín. 2004[cited 2017 Feb 23];23(6)423-8. Available from: http://www.seqc.es/download/revista/63/305/182414725/1024/cms/QC_2004_423-428.pdf/

4. Gutiérrez CG, Medina A. Comparación de los costos reales anuales asociados al manejo ambulatorio de pacientes hipertensos del programa cardiovascular en el hospital comunitario de Bulnes con el pago de prestaciones Fonasa. Rev Chil Cardiol [Internet]. 2011[cited 2017 Feb 13];30(3):207-11. Available from: http://dx.doi.org/10.4067/S0718-85602011000300003

5. Lenz-Alcayaga R. Análisis de costos en evaluaciones económicas en salud: aspectos introductorios. Rev Med Chile [Internet]. 2010[cited 2017 Feb 13];138(Suppl-2):88-92. Available from: http://dx.doi.org/10.4067/S0034-98872010001000006

6. Pérez JA, Fernández E. El sistema de costes y el laboratorio clínico. Ed Cont Lab Clín. 2005;8:33-8.

7. Travers EM, Delahunty DC, Hunter LL, McClatchey KD, Rudar JM. Basic cost accounting for clinical services, approved guideline. NCCLS document GP11-A. ISBN 1-56238-356-6. Wayne, Pennsylvania: NCCLS; 1998.

8. Ávila L, Hernández P, Cruz A, Zurita B, Terres AM, Cruz C. Análisis de productividad, calidad y costos en laboratorios del primer nivel: la biometría hemática. Rev Saúde Pública [Internet]. 1999[cited 2017 Feb 14];33(2):163-70. Available from: http://dx.doi. org/10.1590/S0034-89101999000200008

9. Alvear S, Canteros J, Jara J, Rodríguez P. Costos reales de tratamientos intensivos por paciente y día cama. Rev Med Chile [Internet]. 2013[cited 2017 Feb 13];141(2):202-8. Available from: http://dx.doi.org/10.4067/S0034-98872013000200009

10. Alvear S, Canteros J, Jara J, Rodríguez P. Costeo basado en actividades: una metodología de gestión en tratamientos intensivos. Rev Med Chile [Internet]. 2013[cited 2017 Feb 13];141(11):1371-81. Available from: http://dx.doi.org/10.4067/ S0034-98872013001100002

11. Santelices E, Ormeño H, Delgado M, Lui C, Valdés R, Durán L. Análisis de los determinantes de la eficiencia hospitalaria: el caso de Chile. Rev Méd Chile [Internet]. 2013[cited 2017 Apr 04];141(4):457-63. Available from: http://dx.doi.org/10.4067/ S0034-98872013000400006

12. Brealey RA, Myers SC, Marcus AJ. Fundamentos de finanzas corporativas. Cuarta Edición. Colombia: McGraw-Hill; 2004.

13. FONASA. Fondo Nacional de Salud. Informe final estudio de costos prestaciones de salud, laboratorio e imagenología. Versión 1.1 del 28 de Diciembre año 2016[Internet]. Sub-departamento de Plan de Beneficios. 2016 [cited 2017 Apr 04]. Available from: https://www.fonasa.cl/sites/fonasa/adjuntos/Informe_Final_Estudio_Costos_1

14. Cid C, Bastías G. Evaluando la situación financiera de los hospitales públicos a partir de los costos actualizados de sus prestaciones. Rev Med Chile [Internet]. 2014[cited 2017 Apr 04];142(2):161-7. Available from: http://dx.doi.org/10.4067/ S0034-98872014000200003 